Situs Jurnal : http://ejournal.stiepancasetia.ac.id/index.php/jieb

Jilid 6 Nomor 1 Maret 2020

Hal 38 - 52

\title{
PENGARUH KOMUNIKASI INSTRUKSIONAL TERHADAP SIKAP SISWA MENGENAI BELAJAR KEWIRAUSAHAAN
}

Fakhri

\begin{abstract}
ABSTRAK
Perumusan masalah yang disusun oleh penulis adalah apakah ada pengaruh komunikasi instruksional terhadap sikap siswa mengenai belajar kewirausahaan baik secara parsial maupun simultan, juga penulis merumuskan mana variabel yang paling dominan dari variabel - variabel bebas terhadap variabel terikatnya

Dari hasil penelitian diperoleh persamaan regresi sebagai berikut :

$\mathrm{Y}=0,739+0,382 \mathrm{X}_{1}+0,461 \mathrm{X}_{2}$

Dari hasil tersebut dapat diartikan :

1. Nilai konstanta adalah 0,739 hal ini menyatakan bahwa tanpa adanya pengaruh variabel bebas $X_{1}$ (ceramah) dan $\mathrm{X}_{2}$ (pengajaran), maka nilai dari variabel terikat yaitu Y (sikap siswa) adalah sebesar 0,739.

2. Nilai koefisien regresi dari varibabel bebas $X_{1}$ (ceramah) adalah 0,382 Nilai koefisein tersebut mengandung arti jika nilai variabel bebas $\mathrm{X}_{1}$ ditingkatkan sebesar satu satuan maka akan menyebabkan kenaikan nilai dari variabel terikat yaitu Y (sikap siswa) sebesar 0,382 satuan. Dalam hal ini diasumsikan bahwa nilai dari variabel bebas yang lain adalah konstan atau nol.
\end{abstract}

3. Nilai koefisien regresi dari varibabel bebas $\mathrm{X}_{2}$ (pengajaran) adalah 0,461 . Nilai koefisien tersebut mengandung arti jika nilai variabel bebas $\mathrm{X}_{2}$ ditingkatkan sebesar satu satuan maka akan menyebabkan kenaikan nilai dari variabel terikat yaitu Y (sikap siswa) sebesar 0,461 satuan. Dalam hal ini diasumsikan bahwa nilai dari variabel bebas yang lain adalah konstan atau nol.

Nilai koefisien (R) adalah 0,624 atau mendekati 1 Artinya hubungan antara variabel bebas yang meliputi $\mathrm{X}_{1} \mathrm{X}_{1}$ (ceramah) dan $\mathrm{X}_{2}$ (pengajaran) terhadap variabel terikatnya yaitu sikap siswa kuat searah. Artinya jika variabel bebas yang meliputi $\mathrm{X}_{1}$ (ceramah) dan $\mathrm{X}_{2}$ (pengajaran) ditingkatkan, maka variabel terikat yaitu sikap siswa juga akan naik, demikian pula sebaliknya.

Prosentase pengaruh variabel bebas terhadap variabel terikat yang ditunjukkan oleh koefisien determinasi simultan $\left(\mathrm{R}^{2}\right)$ adalah sebesar 0,589 atau 58,9\%. Hal ini berarti bahwa naik turunnya variabel terikat yaitu sikap siswa dipengaruhi oleh variabel bebas yang meliputi $\mathrm{X}_{1}$ (ceramah) dan $\mathrm{X}_{2}$ (pengajaran) sebesar $58,9 \%$ dan sisanya $41,1 \%$ dipengaruhi oleh variabel lain di luar penelitian ini.

\section{Kata Kunci : Komunikasi, instruksional,sikap siswa.}

\section{PENDAHULUAN}

\subsection{Latar Belakang}

Untuk mewujudkan cita - cita bangsa

dan Negara Indonesia sebagaimana yang diamanatkan dalam Pembukaan Undang undang Dasar 1945 melalui pembangungan nasional sebagai pengamalan Pancasila, dibutuhkan masyarakat yang konsisten dan konsekuen, bertanggung jawab, berorientasi ke masa depan, serta memiliki semangat pengabdian dan kemampuan profesional dalam penyelenggaraan negara dan pembangunan. Peningkatan mutu pendidikan adalah sesuatu hal yang mutlak dilakukan oleh pemerintah dan masyarakat Indonesia agar dapat diciptakan sumberdaya manusia yang memiliki sikap disiplin, profesional, wawasan luas dan semangat pengbadian pada bangsa yang tinggi.
Untuk itu perlu dibuat suatu sistem pendidikan yang berorientasi pada kemampuan dan peningkatan intelektualitas masyarakat serta dapat meningkatkan taraf hidup para guru dan karyawan sekolah. Kemampuan guru menjadi salah satu syarat mutlak bagi peningkatan kualitas pendidikan saat ini. Salah satu kemampuan yang mutlak dimiliki oleh para guru adalah kemampuan berkomunikasi dengan para siswa. Namun perlu disadari bahwa untuk berkomunikasi dengan baik tanpa menyinggung perasaan adalah sesuatu yang tidak mudah. Hal itu tentu saja karena tiap guru mempunyai latar belakang, pengalaman, pengharapan, emosi serta ambisi yang berbeda. Tapi bagaimanapun komunikasi yang baik dan mampu mendorong siswa untuk terus berprestasi adalah hal yang sangat dibutuhkan. 
Terdorong untuk dapat membantu memberikan masukan yang bermanfaat bagi para guru khususnya dalam melakukan komunikasi terhadap siswanya, maka dibuatlah penelitian dengan judul : " Pengaruh Komunikasi Instruksional Terhadap Sikap Siswa Mengenai Belajar kewirausahaan"

\subsection{Rumusan Masalah}

Dari latar belakang yang telah dikemukakan, dapat dirumuskan permasalahan sebagai berikut:

a. Apakah ada pengaruh komunikasi instruksional guru yang berupa ceramah dan pengajaran terhadap sikap siswa mengenai belajar Kewirausahaan

b. Manakah pengaruh komunikasi instruksional guru yang berupa ceramah dan pengajaran yang paling dominan terhadap sikap siswa mengenai belajar Kewirausahaan?

\subsection{Tujuan Penelitian}

Dari rumusan masalah yang telah disusun maka dibuat tujuan penelitian yang akan dilakukan adalah :

a. Untuk mengetahui apakah ada pengaruh komunikasi instruksional guru yang berupa ceramah dan pengajaran terhadap sikap siswa mengenai belajar Kewirausahaan.

b. Untuk mengetahui manakah pengaruh komunikasi instruksional guru yang berupa ceramah dan pengajaran yang paling dominan terhadap sikap siswa mengenai belajar Kewirausahaan

\subsection{Manfaat Penelitian}

Hasil penelitian ini diharapkan dapat memberi manfaat :

1. Bagi Ilmu Pengetahuan

Sebagai sumbangan pemikiran bagi pengembangan ilmu pengertahuan, terutama yang berkaitan dengan topik penelitian.

2. Bagi perusahaan

Sebagai bahan masukan bagi pihak manajemen sekolah dalam menetapkan kebijakan terutama yang berkaitan dengan komunikasi guru terhadap anak didik.

3. Bagi Ilmu Pengetahuan

Sebagai perbendaharaan pengetahuan dan sumbangan pemikiran bagi pihak - pihak yang ingin meneliti masalah yang sama.

4. Bagi Penulis
Sebagai upaya untuk menambah pengetahuan dalam membandingkan antara teori yang penulis peroleh dari perkuliahan dengan kenyataan yang ada di sekolah.

\section{TINJAUAN PUSTAKA}

\section{Komunikasi Instruksional}

Turunan lebih sempit lagi dari aspek komunikasi pendidikan seperti tersebut pada contoh di atas ialah komunikasi instruksional. Di sini komunikasi ditujukan pada aspek aspek operasionalisasi pendidikan, terutama aspek membelajarkan sasaran. Situasi, kondisi, lingkungan, metode, dan termasuk "bahasa" yang digunakan oleh komunikator sengaja dipersiapkan secara khusus untuk mencapai efek perubahan perilaku pada diri sasaran. Dengan kata lain, melalui komunikasi tersebut diharapkan bisa terjadi proses belajar dan mengajar. Beberapa hal bentuk sederhananya dari komunikasi intruksional ini antara lain ialah :

a. kegiatan kuliah,

b. ceramah,

c. mengajar, dan membelajarkan (instruksional).

Dalam hal ini tentu saja tercakup segala kegiatan perancangannya serta segala aspek yang terkait di dalamnya.

Dari ketiga turunan contoh komunikasi tersebut di atas bisa dipahami bahwa komunikasi, pendidikan dan proses instruksional mempunyai bidang garapan yang semakin mengkhusus meskipun pada kedua pengertian yang pertama sebenarnya tidak mutlak karena masing-masing mempunyai bidang kajian yang berbeda. Hal sebaliknya sebenarnya bisa terjadi, bergantung pada konsep mana yang akan diterapkan. Contohnya ialah masalah sistem. Bisa jadi suatu sistem berfungsi sebagai surpa, sementara di tempat lain berkedudukan sebagai sub dalam suatu tatanan organisasi administrasi yang ada di lapangan. Suatu saat komunikasi didudukkan pada tingkat supra, seperti keadaaanya di suatu fakultas ilmu komunikasi dalam lingkungan perguruan tinggi. Pada saat lain dan di tempat lain ia berkedudukan pada tingkat subsistem dari suatu sistem yang berlaku dalam lembaga yang mengindukinya. Contoh yang terakhir ini misalnya jurusan di suatu ilmu sosial dan ilmu politik. Atau bahkan ia hanya berkedudukan sebagai bagian dari suatu sistem pelayanan 
yang ada di perpustakaan dan pusat -pusat informasi.

Kalau komunikasi secara murni mempunyai bidang garapan yang sangat umum dan luas karena meliputi segala aspek kehidupan manusia, dalam pendidikan, bidang kajiannya lebih ditekankan pada aspek - aspek pendewasaan atau pemandirian manusia secara utuh. Sedangkan untuk bidang intruksional ia bersifat lebih langsung menyentuh sasaransasaran yang lebih praktis dan operasional karena di sana terdapat kajian mengenai strategi, metode, teknik, dan taktik melaksanakan tindakan komunikasi dengan harapan terjadi proses perubahan perilaku pada pihak sasaran (komunikan) di dalam situasi dan kondisi medan yang berbeda-beda.

"Instruksional" berasal dari kata instruction, artinya pembelajaran atau pengajaran. Sebenatnya ia merupakan himpunan bagian dari pendidikan. Jadi, pendidikan mempunyai bidang kajian yang lebih luas daripada intruksional. Demikian pula apabila istilah komunikasi "dikawinkan" dengan pendidikan dan "intruksional", terjadi istilah komunikasi pendidikan dan komunikasi intruksional. Istilah yang pertama lebih luas daripada yang kedua karena yang satu merupakan himpunan bagian dari yang lain. Kamunikasi intruksional merupakan himpunan bagian dari komunikasi pendidikan.

Orang mungkin akan bertanya-tanya: apa komunikasi instruksional itu? Adapun sasaran atau lebih luasnya komunikan yang menjadi bagian atau komponen dari komunikasi instruksional ini adalah masyarakat tertentu yang mempunyai sifat kurang heterogen, tetapi juga tidak selalu homogen.

Tambahan untuk ruang lingkup pembahasan ini ialah bahwa komunikator dalam hal ini bisa bertindak hanya sebagai perencana atau perancang atau pembuat model, namun bisa pula sekaligus bertindak langsung sebagai pelaksana komunikasi (instruksional) di lapangan seperti halnya seorang guru, dosen, penceramah, penyuluh, dan pembimbing lapangan.

Komunikasi instruksional mempunyai fungsi edukatif, atau tepatnya mengacu pada fungsi edukatif dari fungsi komunikasi secara keseluruhan. Namun, bukan berarti fungsifungsi lain terabaikan. Akan tetapi, sebagaimana sudah disinggung di muka, komunikasi instruksional merupakan subset dari komunikasi secara keseluruhan. Bahkan apabila dikaitkan dengan bidang pendidikan sekalipun, ia merupakan subset dari komunikasi pendidikan. Ia bersifat metodisteoritis. Artinya, kajian atau garapangarapannya berpola tertentu sehingga akhirnya bisa diterapkan langsung untuk kepentingan di lapangan. Kalau komunikasi pendidikan lebih berarti sebagai proses komunikasi yang terjadi dalam lingkungan kependidikan, baik secara teoritis maupun secara praktis, komunikasi instruksional lebih ditekankan kepada pola perencanaan dan pelaksanaan secara operasional yang didukung oleh teori untuk kepentingan keberhasilan efek perubahan perilaku pada pihak sasaran (komunikan). Efek perubahan perilaku inilah yang tampaknya merupakan tujuan sasaran akhir dari pelaksanaan komunikasi instruksional.

Dengan demikian, karena komunikasi instruksional ini mempunyai tujuan yang harus dicapai, dalam pelaksanaan kegiatannya, ia mempunyai fungsi-fungsi "teknis", antara lain fungsi manajemen instruksional dan fungsi pengembangan instruksional. Yang pertama merupakan fungsi pengelolaan organisasi dan pengelolaan personel, sedangkan yang kedua mempunyai fungsi riset-teori, desain, produksi, evaluasi, seleksi, logistik, pemanfaatan, dan penyebaran. Kesemua fungsi tersebut diarahkan kepada optimalisasi pemanfaatan komponen sumber-sumber belajar (sumber informasi edukatif) dalam rangka berupaya memberhasilkan proses belajar secara tuntas.

Adapun manfaat adanya komunikasi instruksional antara lain ialah efek perubahan perilaku, yang terjadi sebagai hasil tindakan komunikasi instruksional, bisa dikontrol atau dikendalikan dengan baik. Berhasil tidaknya tujuan-tujuan instruksional yang telah ditetapkan paling tidak bisa dipantau melalui kegiatan evaluasi yang juga merupakan fungsi pengembangan tadi. Lebih-lebih apabila kegiatan instruksional ini sudah memanfaatkan jasa teknologi, seperti misalnya teknologi instruksional dan media instruksional, manfaatnya akan menjadi semakin nyata.

Pengertian komunikasi instruksional dalam hal ini lebih dititikberatkan kepada usaha merubah perilaku khalayak sasaran belajar (komunikan) oleh komunikator atau para praktisi komunikasi lain dalam melaksanakan 
tugasnya di lapangan, dengan menggunakan proses komunikasi yang direncanakan secara khusus sesuai dengan situasi dan kondisi yang diperkirakan lebih dapat mempercepat terjadinya proses belajar. Di sini kata instruksional, yang berasal dari instructional (instruction), tidak diartikan sebagai komando atau perintah, namun lebih tepat sebagai upaya membelajarkan, menyuruh anak untuk belajar sendiri, atau membuat situasi dan kondisi lingkungan sedemikian rupa sehingga anak atau khalayak sasaran mau belajar sendiri. Istilah lain yang juga sering muncul untuk kata instruksional adalah pembelajaran.

\section{Sikap Siswa}

Sikap atau attitude adalah suatu konsep paling penting dalam psikologi sosial. Pembahasan yang berkaitan dengan psikologi (sosial) hampir selalu menyertakan unsur sikap baik sikap individu maupun sikap kelompok sebagai salah satu bagian pembahasannya. Banyak kajian dilakukan untuk merumuskan pengertian sikap, proses terbentuknya sikap, maupun proses perubahannya. Banyak pula penelitian telah dilakukan terhadap sikap untuk mengetahui efek dan perannya baik sebagai variabel bebas maupun sikap sebagai variabel tergantung.

Thursthoen dalam Walgito (1990: 108) menjelaskan bahwa, sikap adalah gambaran kepribadian seseorang yang terlahir melalui gerakan fisik dan tanggapan pikiran terhadap suatu keadaan atau suatu objek. Berkowitz, dalam Azwar (2000:5) menerangkan sikap seseorang pada suatu objek adalah perasaan atau emosi, dan faktor kedua adalah reaksi / respon atau kecenderungan untuk bereaksi. Sebagai reaksi maka sikap selalu berhubungan dengan dua alternatif, yaitu senang (like) atau tidak senang (dislike), menurut dan melaksanakan atau menjauhi/menghindari sesuatu.

\section{BAHASAN}

\subsection{Jenis Penelitian}

Jenis penelitian ini masuk dalam kategori penelitian explanatory, atau penelitian yang bersifat penjelasan suatu fenomena yang terjadi serta menyoroti hubungan antara variabel - variabel yang diteliti dan menguji hipotesis yang telah dirumuskan sebelumnya. Sedangkan informasi data secara primer dikumpulkan dari responden dengan menggunakan kuesioner.

Penelitian ini termasuk penelitian survei yang merupakan penyelidikan yang diadakan untuk memperoleh keadaan secara nyata mengenai fenomena - fenomena yang terjadi pada obyek penelitian. Kerlinger (1973) mengemukakan bahwa penelitian survey adalah penelitian yang pada populasi besar maupun kecil tetapi data yang dipelajari adalah data dari sampel yang diambil dari populasi dan hubungan antara variabel - variabel secara sosiologis maupun biologis

\subsection{Populasi dan Sampel}

Populasi menurut Singarimbun dan Efendi (1999) adalah jumlah keseluruhan dari unit pengamatan yang ciri - cirinya akan diperkirakan. Sedangkan Sugiyono (1994) memberikan pengertian tentang populasi adalah wilayah generalisasi yang terdiri dari obyek / subyek yang mempunyai kuantitas dan karakteristik tertentu yang ditetapkan oleh peneliti untuk dipelajari kemungkinan ditarik kesimpulannya.

Sampel menurut Sugiyono (1994) adalah sebagian dari jumlah dan karakteristik yang dimiliki oleh populasi tersebut. Jumlah sampel dalam penelitian ini sebanyak 48 orang

\subsection{Definisi Operasional dan Identifikasi Variabel}

Dalam penelitian ini digunakan beberapa variabel meliputi variabel terikat/ dependent variable (Y) dan variabel bebas / independent variable (X) yang dapat diklasifikasikan sebagai berikut :

\section{Variabel Terikat / dependent variable (Y)}

Variabel terikat adalah variabel yang dipengaruhi yang akan diteliti dalam penelitian ini, yaitu sikap siswa (Y) yang didefiniskan sebagai kecenderungan, pandangan, pendapat atau pendirian seseorang untuk menilai suatu objek atau persoalan dan bertindak sesuai dengan penilaiannya dengan menyadari perasaan positif dan negatif dalam menghadapi suatu objek. Indikator sikap pada penelitian ini adalah :

a. Kemampuan pemahaman

b. Kemampuan penerapan 


\section{Variabel Bebas / Independent Variable}

(X)

Variabel-variabel independen terdiri dari variabel komunikasi instruksional yang terdiri dari :

a. Ceramah (X1)

Indikatornya adalah :

1) Materi ceramah

2) Metode ceramah

3) Kemampuan penceramah

b. Pengajaran (X2)

Indikatornya adalah :

1) Situasi sekolah

2) Lingkungan sekolah

3) Metode pembelajaran

\subsection{Teknik Pengumpulan Data}

Beranjak dari sumber-sumber data tersebut di atas, peneliti dalam mengumpulkannya menggunakan teknik :

1. Teknik observasi, yaitu proses preliminary study dalam rangka mengenal dan memahami para siswa yang akan menjadi responden penelitian. Dengan cara demikian, peneliti mendapatkan informasi mengenai karakteristik para siswa.

2. Teknik wawancara, yaitu proses dalam rangka mendapatkan karakteristik para siswa. Apabila sesuai dengan kriteria maka calon responden diberikan daftar pertanyaan untuk diisi.

\subsection{Metode Analisis Data}

1. Uji Asumsi Klasik

Untuk menilai independensi setiap variabel bebas maka perlu memenuhi asumsi asumsi klasik agar diperoleh hasil yang tidak bias dan efisien dari model analisis Regresi Linear Berganda dengan metode kuadrat terkecil atau OLS (Ordinary Least Square) terhadap variabel yang diamati. Adapun uji asumsi klasik yang digunakan sebagai berikut :

a. Tidak ada multikolinieritas

Multikolinieritas merupakan suatu keadaan dimana terjadi satu atau lebih variabel bebas yang berkorelasi sempurna atau mendekati sempurna dengan variabel bebas lainnya. Salah satu cara untuk mengetahui gejala ini adalah dengan Variance Inflation Faktor (VIF) dari masing -masing variabel bebas terhadap variabel terikat. Jika nilai VIF tidak lebih dari 5 maka mengidentifikasikan bahwa tidak terdapat gejala multikolonieritas.

b. Tidak adanya gejala heteroskedastisitas Heteroskedastisitas merupakan suatu keadaan dimana masing - masing kesalahan pengganggu memiliki varian yang berlainan. Pengujiannya dilakukan dengan menggunakan uji korelasi Rank Sprearman, yaitu mengkorelasikan antar absolut residual hasil regresi dengan semua variabel bebas. Jika signifikansi hasil korelasi lebih kecil dari 0,05 (5\%) maka disimpulkan persamaan regresi tersebut mengandung heteroskedastisitas. Dan sebaliknya berarti non heteroskedastisitas atau homokedastisitas.

c. Pengujian Autokorelasi

Dalam suatu analisa regresi dimungkinkan terjadinya hubungan antara variabel - variabel bebas itu sendiri atau berkorelasi sendiri. Prosedur pendeteksian masalah autokorelasi menggunakan pengujian Durbin Watson. Sugiyono(2004) mengatakan bahwa nilai Durbin - Watson digunakan untuk menentukan uji autokorelasi dengan ketentuan apabila nilai Durbin Watson di bawah 5 maka tidak terjadi autokorelasi.

d. Asumsi Normalitas

Pengujian normalitas ini perlu dilakukan, untuk mengetahui model yang dibuktikan merupakan model linear atau tidak. Pengujian normalitas dilakukan dengan melihat scatterplot. Bila sebaran tidak menunjukkan pola tertentu maka asumsi normalitas memenuhi persyaratan

\section{Pengujian Instrumen}

\section{a. Uji Validitas}

Validitas menunjukan sejauh mana suatu alat ukur (kuesioner) dapat mengukur informasi yang diperlukan. Uji validitas data dapat dilakukan dengan total pengamatan menggunakan rumus korelasi Spearman's : 


$$
r_{s}=1-6\left[\frac{\Sigma d^{2}}{N\left(N^{2}-1\right)}\right]
$$

Keterangan :

$$
\begin{aligned}
& r_{s}=\text { koefisien korelasi } \\
& \mathrm{d}=\text { perbedaan antara pasangan }- \\
& \text { pasangan urutan } \\
& \mathrm{N}=\text { Jumlah siswa yang ada } \\
& \text { Hipotesis yang berlaku adalah sebagai } \\
& \text { berikut : } \\
& \text { Ho }: \mathrm{r}=0 \\
& \mathrm{H} 1: \mathrm{r} \neq 0 \\
& \text { Pernyataan dinyatakan valid jika r hitung } \\
& \text { besar dari } \mathrm{r} \text { tabel korelasi pada derajad } \\
& (\mathrm{db}) \mathrm{n}-2 \text { atau jika nilai probabilitas < } \\
& 0,05
\end{aligned}
$$

\section{b. Uji Reliabilitas}

Reliabilitas atau keandalan dilakukan untuk mengetahui sampai sejauh mana kuesioner yang diajukan dapat memberikan hasil yang tidak berbeda jika dilakukan pengukuran kembali terhadap subyek yang sama pada waktu yang berlainan. Seperti dinyatakan oleh Supranto (1997:125) bahwa, suatu kuesioner disebut mempunyai reliabilitas atau dapat dipercaya, jika kuesioner itu stabil, dan dapat diandalkan sehingga karena penggunaan kuesioner tersebut berkali-kali akan memberikan hasil yang serupa.

Dalam penelitian ini uji reliabilitas dilakukan dengan melihat koefisien Alpha Cronbach yang dirumuskan sebagai berikut :

dimana :

$$
\alpha=\frac{\mathrm{r}}{1=(\mathrm{k}-1) \mathrm{r}}
$$

$\alpha=$ keandalan Alpha Cronbach

$\mathrm{k}=$ jumlah pernyataan dalam skala

$\mathrm{r} \quad=$ rata-rata korelasi diantara butir pernyataan

teknik ini dilakukan pada pernyataanpernyataan handal, sedangkan kriterianya menurut Arikunto (1993:56) sebagai berikut.

Tabel 3.1

Indeks Kriteria Reliabilitas

\begin{tabular}{|c|c|c|}
\hline No & $\begin{array}{c}\text { Interval Alpha } \\
\text { Cronbach }\end{array}$ & Kriteria \\
\hline
\end{tabular}

\begin{tabular}{|l|l|c|}
\hline 1 & $<0,200$ & Sangat rendah \\
\hline 2 & $0,200-0,399$ & Rendah \\
\hline 3 & $0,400-0,599$ & Cukup \\
\hline 4 & $0,600-0,799$ & Tinggi \\
\hline 5 & $0,800-1,000$ & Sangat tinggi \\
\hline
\end{tabular}

Sumber : Suharsimi (1998:56)

\subsection{Analisis Regresi Berganda}

\section{Model Regresi Linear Berganda}

Untuk menganalisis pengaruh masingmasing variabel bebas terhadap variabel terikat, baik secara simultan maupun secara parsial dirumuskan model regresi linear berganda berikut ini (Supranto, $1993: 229$ )

$$
\begin{aligned}
& \mathbf{Y}=\mathbf{B}_{0}+\mathbf{B}_{1} \mathbf{X}_{1}+\mathbf{B}_{2} \mathbf{X}_{2}+\mathbf{e} \\
& \text { dimana : } \\
& \mathrm{Y}=\text { Sikap Siswa } \\
& \mathrm{B}_{1}, \mathrm{~B}_{2}, \quad=\text { adalah koefisien regresi } \\
& \text { dari masing-masing } \\
& \text { variabel independen } X_{1} \text {, } \\
& \mathrm{X}_{2} \text {. } \\
& \mathrm{B}_{0} \quad=\text { Konstanta } \\
& \text { e } \quad=\text { adalah error atau sisa } \\
& \text { (residual) } \\
& \mathrm{X} 1=\text { Ceramah } \\
& \text { X2 }=\text { Pengajaran }
\end{aligned}
$$

\section{Uji Asumsi Klasik}

Evaluasi ekonometrika digunakan untuk mengetahui apakah model regresi linear berganda yang digunakan untuk analisis ini telah memenuhi asumsi klasik dalam arti bahwa model yang digunakan tepat dan menghasilkan nilai yang akurat. Asumsi klasik yang dimaksud diuraikan pada berikut ini.

\section{Kolinearitas Ganda (Multicolinearity)}

Kolinearitas ganda terjadi apabila terdapat hubungan yang sempurna atau hampir sempurna antara variabel bebas, sehingga sulit untuk memisahkan pengaruh tiap-tiap variabel itu secara individu terhadap variabel terikat. Untuk mengetahui ada tidaknya Multicolinearity, digunakan pendekatan uji VIF. Apabila dalam model regresi ini ternyata mempunyai kolinearitas ganda, maka cara penanggulangannya, yaitu (Supranto, 1997 : 177) : (1) memeriksa secara teoritis untuk 
mengetahui apakah antara variabel penjelas itu memang ada hubungannya; (2) mengadakan penggabungan antara dua cross-section dan time series, yang akan disebut sebagai pooling data; (3) mengeluarkan salah satu variabel penjelas dari model tersebut; (4) mentransformasi variabel yang ada dalam model; (5) menambah data baru, yaitu menambah jumlah observasi atau $\mathrm{n}$, dengan semakin besarnya $\mathrm{n}$, maka ada kemungkinan bahwa standard error akan semakin kecil pula.

\section{Heterokedastisitas}

Digunakan untuk mengetahui apakah kesalahan pengganggu mempunyai varian yang sama. Pengujian dilakukan dengan menggunakan uji glejser dengan langkahlangkah sebagai berikut (Supranto, 1997 : 187)

a. melakukan regresi variabel terikat $\mathrm{Y}$ terhadap semua variabel penjelas $\mathrm{Xi}$ dan memperoleh nilai residual ( $\mathrm{lel}$ );

b. melakukan regresi dari nilai absolut residual ( $\mid \mathrm{el}$ ) terhadap $\mathrm{Xi}$ yang mempunyai hubungan erat dengan $\delta^{2} \mu$ dengan bentuk regresi sebagai berikut: |el $=\partial_{0}+\partial_{1} X_{1}+\mu_{i}$

c. menentukan ada tidaknya heterokedastisitas dalam uji statistik, untuk menguji hipotesis: $\mathrm{H}_{0}: \partial_{1}=0$ dan $\mathrm{H}_{1}: \partial_{1} \neq 0$

d. kriteria pengambilan keputusan :

1)

Apabila probabilitas $-\mathrm{t}_{\text {tabel }}<\mathrm{t}_{\text {hitung }}$ $<\mathrm{t}_{\text {tabel}}$, maka dalam model tidak terjadi heterokedastisitas;

2)

$$
\begin{aligned}
& \text { Apabila probabilitas } t_{\text {hitung }}<-t_{\text {tabel }} \\
& \text { atau } t_{\text {hitung }} \geq \mathrm{t}_{\text {tabel}} \text {, maka dalam } \\
& \text { model ini terjadi } \\
& \text { heterokedastisitas. }
\end{aligned}
$$

Apabila terjadi heteroskedastisitas, maka perlu dicari jalan keluarnya, yakni dengan cara melakukan transformasi model. Jalan keluar yang bisa ditempuh adalah (Supranto, 1997 : 190) dengan melihat apakah varians itu diketahui atau tidak. Jika varians diketahui, maka penyelesaian nilai yang harus diduga dilakukan dengan mempergunakan metode kuadrat terkecil tertimbang. Jika varians tidak diketahui (pada umumnya dari hasil penelitian varians tidak diketahui) selanjutnya analisis kebanyakan dilakukan melalui proses transformasi dari model linear asalnya.

\section{Otokorelasi}

Otokorelasi terjadi bila terdapat hubungan yang signifikan antara dua data yang berdekatan. Korelasi tersebut dinamakan korelasi serial untuk data time series dan disebut otokorelasi parsial untuk data cross section. Kenyataan yang diharapkan adalah otokorelasi itu tidak ada dengan penjelasan sebagai berikut :

Korelasi dari disturbance term suatu observasi dengan observasi lainnya (baik time series maupun cross sectional)

$\rightarrow \quad \mathrm{E}(\mu \mathrm{i}, \mu \mathrm{j}) \neq 0 \quad \mathrm{i} \neq \mathrm{j}, 1 \neq 2,2 \neq 3 \mathrm{dst}$

\section{Durbin - Watson Test}

- Mengestimasi model dan menghitung residualnya

- Menghitung Durbin Watson statistic

$$
\mathrm{d}=\frac{\Sigma^{\mathrm{n}} \mathrm{t}-2(\mathrm{et}-\mathrm{et}-1)^{2}}{\sum^{\mathrm{n}} \mathrm{t}-1 . \mathrm{et}^{2}}
$$

Memformulasikan hipotesis

Ho $=\rho: 0 \quad$ tidak adaautocorrelation

Ho $=\rho>0$ ada positif autocorrelation

Ho $=\rho<0$ ada negatif autocorrelation

Apabila suatu model mengandung otokorelasi, maka model tersebut perlu ditransformasi. Cara transformasi itu tergantung dari struktur otokorelasinya. Jika struktur otokorelasi diketahui, maka diperlukan sebaran normal dan jika struktur otokorelasi tidak diketahui (dalam prakteknya struktur otokorelasi tidak diketahui) untuk menanggulanginya dipergunakan metoda beda pertama.

\section{Pengujian Hipotesis}

Hipotesis penelitian diuji melalui tahapan berikut ini.

\section{Koefisien determinan berganda $\left(\mathbf{R}^{2}\right)$}

Yaitu melakukan pengukuran persentase pengaruh masing-masing variabel bebas/ independent variable terhadap variabel terikat/ dependent variable dimana hasilnya dapat dilihat dari hasil perhitungan dengan menggunakan komputer program SPSS release 16.

2. Uji koefisien regresi secara simultan / bersama-sama ( $\mathbf{F}$ ) 
Yaitu pengujian yang dilakukan untuk mengetahui apakah semua variabel bebas / independent variable secara bersama-sama (simultan) dapat mempengaruhi variabel terikat / dependent variable dan dilakukan dengan cara membandingkan antara $\mathrm{P}$ value dengan $\alpha=5 \%$. Adapun nilai F hitung dirumuskan berikut ini :

$$
F_{\text {hitung }}=\frac{\mathrm{R}^{2} /(\mathrm{k}-1)}{\left(1-\mathrm{R}^{2}\right) /(\mathrm{n}-\mathrm{k})}
$$

dimana :

$$
\begin{aligned}
& \mathrm{k}=\text { jumlah vaiabel bebas } \\
& \mathrm{n}=\text { jumlah pengamatan }
\end{aligned}
$$

Kriteria keputusan adalah pada berikut ini :

a. Jika $\mathrm{P}$ value $>\alpha$ berarti variabel-variabel independen secara simultan tidak mempunyai pengaruh yang signifikan terhadap variabel dependen

b. Jika $\mathrm{P}$ value $<\alpha$ bearti variabel-veriabel independen secara simultan mempunyai pengaruh yang signifikan terhadap variabel dependen

\section{Uji secara parsial $(t)$}

Yaitu pengujian yang dilakukan untuk mengetahui apakah masing-masing variabel bebas/independent variable secara sendirisendiri (parsial) dapat mempengaruhi variabel terikat/dependent variable dan dilakukan dengan cara membandingkan $\mathrm{P}$ value dengan $\alpha=5 \%$. Adapun rumus nilai thitung adalah :

$$
\mathrm{t}_{\text {hitung }}=\frac{\mathrm{b}-\mathrm{B}}{\mathrm{S}}
$$

dimana :

$\mathrm{b}=$ Koefisien regresi parsial sampel

$\mathrm{B}=$ Koefisien regresi parsial populasi

$\mathrm{S}=$ Standart eror regresi sampel

Kriteria keputusan adalah pada berikut ini :

a Jika $\mathrm{P}$ value $>\alpha$ berarti variabel-variabel independen secara parsial tidak mempunyai pengaruh yang signifikan terhadap variabel dependen

b Jika $\mathrm{P}$ value $<\alpha$ berarti variabel-variabel independen secara parsial mempunyai pengaruh yang signifikan terhadap variabel dependen

\section{Uji Variabel Dominan}

Untuk mengkaji variabel yang dominan digunakan indikator koefisien Beta Standardized dari variabel-variabel dalam model regresi Koefisien Beta Standardized diperoleh dari hasil perkalian antara koefisien parsial korelasi $\frac{S D x 1}{S D y}$ dan koefisien variabelnya (bi).

Dengan demikian rumus Koefisien Beta Standardized adalah :

$$
\frac{\underline{S D x}_{1}}{\text { SDy }}=\text { bi }
$$

Penetapan variabel yang dominan dilakukan berdasarkan Koefisien Beta Standardized yang terbesar.

\section{ANALISIS DAN PEMBAHASAN} 4.1 Analisa Hasil Penelitian

Dari kuesioner yang disampaikan kepada para responden yang berjumlah 48 orang, maka diperoleh data rata - rata variable sebagai berikut :

TABEL 4.1

REKAP DATA RESPONDEN

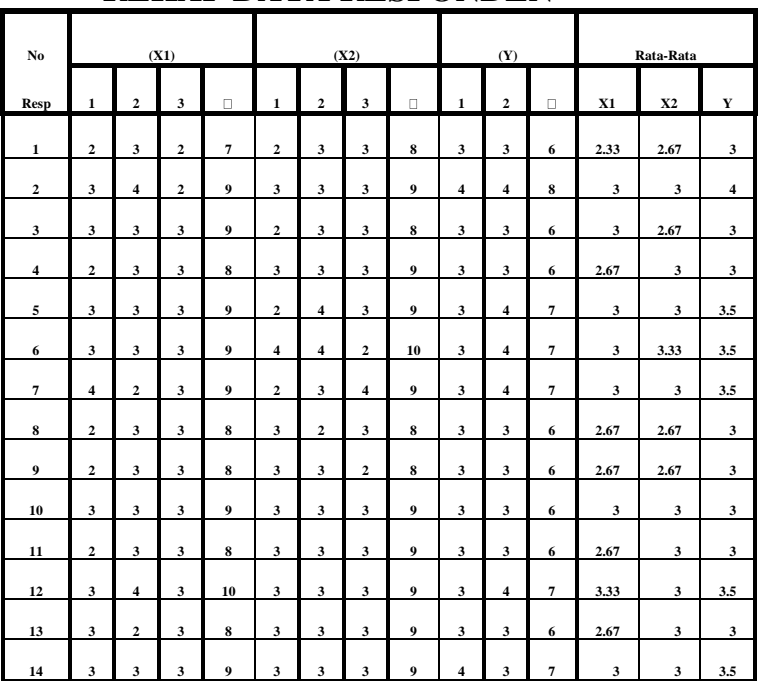

JIEB, Jilid 6, No 1,19 Maret 2020 


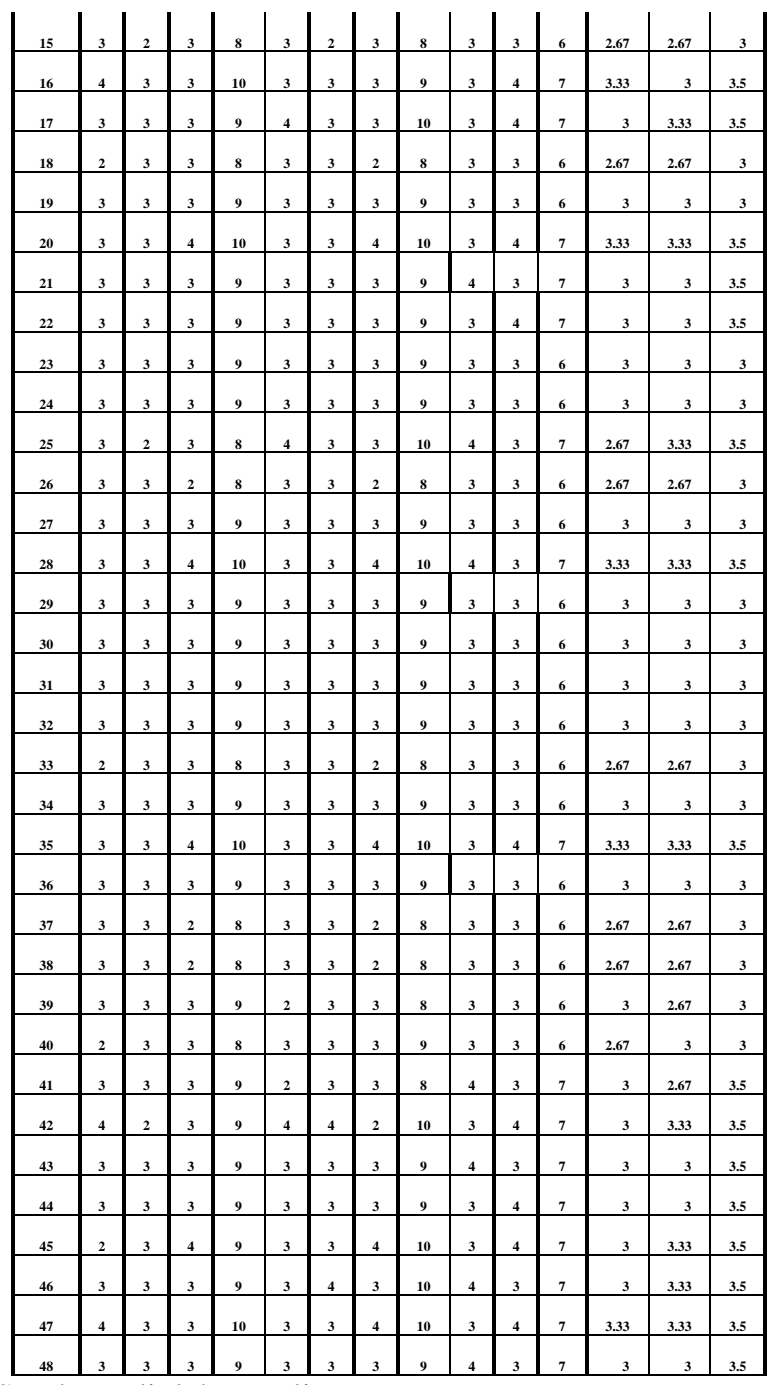

Sumber : diolah penulis

Dalam pembahasan pada bab ini dibahas masalah hasil penelitian yaitu uji reliabilitas, uji asumsi klasik,analisis regresi linear berganda, uji t serta uji f.

\section{Uji Validitas}

Dari hasil perhitungan teknik korelasi product moment dengan menggunakan SPSS diperoleh hasil bahwa semua dari item pertanyaan yang diajukan kepada responden mempunyai korelasi yang yang tinggi $(>0,50)$ dengan variabel yang bersangkutan. Dengan demikian bisa dikatakan bahwa semua indikator pengukuran yang dipergunakan dalam penelitian ini memiliki validitas yang tinggi. Adapun untuk mengetahui suatu item penyataan tersebut dikatakan valid jika terdapat korelasi yang signifikan yang ditunjukkan dengan nilai signifikansi kurang dari $\alpha=0,05$.

TABEL 4.2

\begin{tabular}{|c|c|c|c|c|c|}
\hline \multicolumn{6}{|c|}{ Correlations } \\
\hline & & $\mathrm{x} 1.1$ & $\mathrm{x} 1.2$ & $\mathrm{x} 1.3$ & $\mathrm{x} 1$ \\
\hline \multirow[t]{3}{*}{$\mathrm{x} 1.1$} & Pearson Correlation & 1 & -.251 & -.010 & $.617^{* *}$ \\
\hline & Sig. (2-tailed) & & .086 & .947 & .000 \\
\hline & $\mathrm{N}$ & 48 & 48 & 48 & 48 \\
\hline \multirow[t]{3}{*}{$\mathrm{x} 1.2$} & Pearson Correlation & -.251 & 1 & -.136 & $.285^{\circ}$ \\
\hline & Sig. (2-tailed) & .086 & & .357 & .049 \\
\hline & $\mathrm{N}$ & 48 & 48 & 48 & 48 \\
\hline \multirow[t]{3}{*}{$\mathrm{x} 1.3$} & Pearson Correlation & -.010 & -.136 & 1 & $.565^{* *}$ \\
\hline & Sig. (2-tailed) & .947 & .357 & & .000 \\
\hline & $\mathrm{N}$ & 48 & 48 & 48 & 48 \\
\hline \multirow[t]{3}{*}{$\mathrm{x} 1$} & Pearson Correlation & $.617^{* *}$ & $.285^{*}$ & $.565^{* *}$ & 1 \\
\hline & Sig. (2-tailed) & .000 & .049 & .000 & \\
\hline & $\mathrm{N}$ & 48 & 48 & 48 & 48 \\
\hline
\end{tabular}

Sumber : Print Out SPSS

Dari print out SPSS di atas dapat diringkas sebagai berikut :

Tabel 4.3

Uji Validitas untuk X1

\begin{tabular}{|l|c|c|c|}
\hline Indikator & $\begin{array}{c}\text { Nilai } \\
\text { Korelasi }\end{array}$ & Signifikan & Keterangan \\
\hline X1.1 & 0,793 & 0,000 & Valid \\
\hline X1.2 & 0,631 & 0,000 & Valid \\
\hline X1.3 & 0,488 & 0,006 & Valid \\
\hline
\end{tabular}

\section{Sumber : Print Out SPSS}

Dari tabel di atas dapat disimpulkan bahwa indikator X1 adalah valid.

Tabel 4.4 


\begin{tabular}{|c|c|c|c|c|c|}
\hline \multicolumn{6}{|c|}{ Correlations } \\
\hline & & $\mathrm{x} 2.1$ & $\mathrm{x} 2.2$ & $\mathrm{x} 2.3$ & $\mathrm{x} 2$ \\
\hline \multirow[t]{3}{*}{$\mathrm{x} 2.1$} & Pearson Correlation & 1 & .141 & -.262 & $.537^{* *}$ \\
\hline & Sig. (2-tailed) & & .338 & .072 & .000 \\
\hline & $\mathrm{N}$ & 48 & 48 & 48 & 48 \\
\hline \multirow[t]{3}{*}{$\mathrm{x} 2.2$} & Pearson Correlation & .141 & 1 & -.211 & $.446^{* *}$ \\
\hline & Sig. (2-tailed) & .338 & & .150 & .001 \\
\hline & $\mathrm{N}$ & 48 & 48 & 48 & 48 \\
\hline \multirow[t]{3}{*}{$\mathrm{x} 2.3$} & Pearson Correlation & -.262 & -.211 & 1 & $.511^{* *}$ \\
\hline & Sig. (2-tailed) & .072 & .150 & & .000 \\
\hline & $\mathrm{N}$ & 48 & 48 & 48 & 48 \\
\hline \multirow[t]{3}{*}{$\mathrm{x} 2$} & Pearson Correlation & $.537^{* *}$ & $.446^{* *}$ & $.511^{* *}$ & 1 \\
\hline & Sig. (2-tailed) & .000 & .001 & .000 & \\
\hline & $\mathrm{N}$ & 48 & 48 & 48 & 48 \\
\hline
\end{tabular}

**. Correlation is significant at the 0.01 level (2-tailed).

Sumber :Print Out SPSS

Dari print out SPSS di atas dapat diringkas sebagai berikut :

Tabel 4.5

Uji Validitas untuk X2

\begin{tabular}{|l|c|c|c|}
\hline Indikator & Nilai Korelasi & Signifikan & Keterangan \\
\hline X2.1 & 0,562 & 0,001 & Valid \\
\hline X2.2 & 0,573 & 0,043 & Valid \\
\hline X2.3 & 0,621 & 0,041 & Valid \\
\hline X2.4 & 0,502 & 0,005 & Valid \\
\hline
\end{tabular}

Sumber : Print Out SPSS

Dari tabel di atas dapat disimpulkan bahwa indikator X2 adalah valid.

Tabel 4.6

\begin{tabular}{|c|c|c|c|c|}
\hline \multicolumn{5}{|c|}{ Correlations } \\
\hline & & y.1 & y. 2 & $\mathrm{y}$ \\
\hline \multirow[t]{3}{*}{ y.1 } & $\begin{array}{l}\text { Pearson } \\
\text { Correlation }\end{array}$ & 1 & -.191 & $.563^{* *}$ \\
\hline & Sig. (2-tailed) & & .194 & .000 \\
\hline & $\mathrm{N}$ & 48 & 48 & 48 \\
\hline \multirow[t]{3}{*}{ y. 2} & $\begin{array}{l}\text { Pearson } \\
\text { Correlation }\end{array}$ & -.191 & 1 & $.704^{* *}$ \\
\hline & Sig. (2-tailed) & .194 & & .000 \\
\hline & $\mathrm{N}$ & 48 & 48 & 48 \\
\hline \multirow[t]{3}{*}{$\mathrm{y}$} & $\begin{array}{l}\text { Pearson } \\
\text { Correlation }\end{array}$ & $.563^{* *}$ & $.704^{* *}$ & 1 \\
\hline & Sig. (2-tailed) & .000 & .000 & \\
\hline & $\mathrm{N}$ & 48 & 48 & 48 \\
\hline
\end{tabular}

**. Correlation is significant at the 0.01 level (2-tailed).

Sumber :Print Out SPSS
Dari print out SPSS di atas dapat diringkas sebagai berikut :

Tabel 4.7

Uji Validitas untuk Y

\begin{tabular}{|c|c|c|c|}
\hline Indikator & $\begin{array}{c}\text { Nilai } \\
\text { Korelasi }\end{array}$ & Signifikan & Keterangan \\
\hline Y.1 & 0,741 & 0,000 & Valid \\
\hline Y.2 & 0,699 & 0,000 & Valid \\
\hline Y.3 & 0,440 & 0,015 & Valid \\
\hline
\end{tabular}

Sumber : Print Out SPSS

Dari tabel di atas dapat disimpulkan bahwa indikator $\mathrm{Y}$ adalah valid.

Dari semua data yang disajikan menunjukkan bahwa seluruh butir item pertanyaan memiliki nilai signifikansi kurang dari 0,05 dengan demikian terbukti bahwa seluruh butir pertanyaan yang diajukan kepada responden adalah valid.

\section{Pengujian Reliabilitas}

Reliabilitas yang dimaksud pada suatu penelitian bahwa suatu instrumen dapat dipercaya untuk digunakan sebagai alat pengumpul data karena instrumen tersebut adalah baik. Suatu alat ukur dikatakan reliabel jika kita selalu mendapatkan hasil yang sama dari gejala pengukuran yang tidak berubah yang dilakukan pada waktu yang berbeda - beda. Untuk mengukur reliabilitas dari suatu analisis dapat digunakan koefisien apabila yang di dasarkan pada butir data instrumen pengukuran. Pada hasil uji reliabilitas dengan uji statistik Cronbach Alpha diketahui bahwa dikatakan reliabel apabila memberikan nilai cronbach alpha > 0,6 (Nunnally, 1969)

Reliability Statistics X1

\begin{tabular}{|c|c|}
\hline $\begin{array}{c}\text { Cronbach's } \\
\text { Alpha }\end{array}$ & $\mathrm{N}$ of Items \\
\hline .558 & 4 \\
\hline \multicolumn{2}{|c|}{ Reliability Statistics X2 } \\
\hline $\begin{array}{c}\text { Cronbach's } \\
\text { Alpha }\end{array}$ & $\mathrm{N}$ of Items \\
\hline .648 & 4 \\
\hline \multicolumn{2}{|c|}{ Reliability Statistics Y } \\
\hline $\begin{array}{c}\text { Cronbach's } \\
\text { Alpha }\end{array}$ & $\mathrm{N}$ of Items \\
\hline .663 & 3 \\
\hline
\end{tabular}

Dari hasil print out SPSS tersebut dapat dibuat table reliabilitas sebagai berikut :

Tabel 4.8 
Uji Reliabilitas

\begin{tabular}{|l|c|l|}
\hline Variabel & $\begin{array}{c}\text { Nilai } \\
\text { Alpha Crombath }\end{array}$ & Keterangan \\
\hline Ceramah (X1) & 0,558 & Reliabel \\
\hline Pengajaran (X2) & 0,648 & Reliabel \\
\hline Sikap siswa (Y) & 0,663 & Reliabel \\
\hline
\end{tabular}

Sumber : Print Out SPSS

Dari hasil perhitungan pada lampiran SPSS dapat diketahui bahwa nilai Cronbach's Alpha pada setiap item pertanyaan yang ada pada tiap variabel yang diteliti adalah di atas 0,6 maka dapat dikatakan bahwa kuesioner pada penelitian ini adalah reliabel.

\section{Uji Asumsi Klasik}

\section{a. Uji Normalitas}

Uji normalitas bertujuan untuk menguji apakah dalam model regresi, variabel terikat dan variabel bebas kedua - duanya memiliki distribusi normal atau tidak. Model regresi yang baik adalah memiliki distribusi data normal atau mendekati normal. Salah satu cara termudah untuk melihat normalitas adalah dengan melihat normal probability plot. Distribusi normal akan membentuk suatu garis lusus diagonal dan ploting data akan dibandingkan dengan garis normal. Jika distribusi data adalah normal maka garis yang menggambarkan data sesungguhnya akan mengikuti garis diagonalnya. Hasil pengolahan SPSS yang menunjukkan grafis dari Normal Probability Plot adalah sebagai berikut :

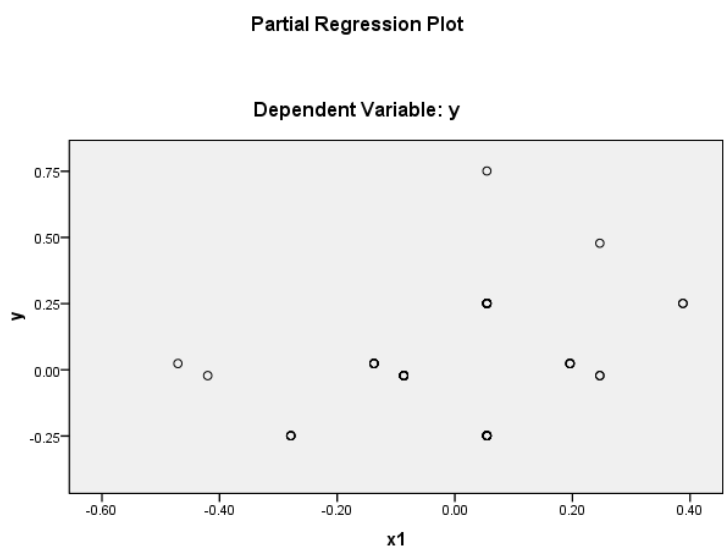

Karena data tersebar di sekitar garis plot maka data dari variabel X1 adalah dapat dikatakan normal.

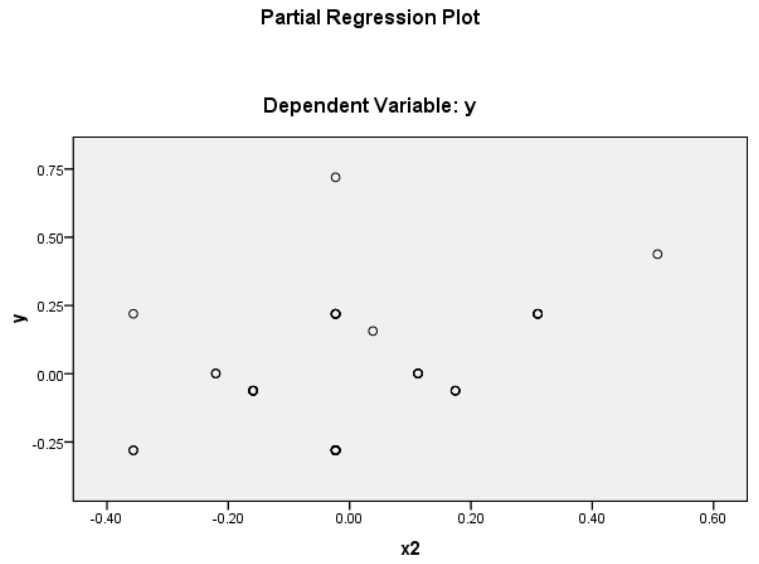

Karena data tersebar di sekitar garis plot maka data dari variabel X2 adalah dapat dikatakan normal.

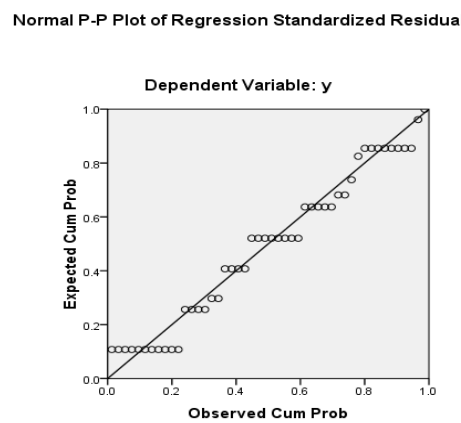

Dari gambar tersebut dapat diketahui bahwa titik titik menyebar di sekitar garis diagonal,oleh sebab itu penelitian ini memenuhi asumsi normalitas.

\section{b. Uji Multikolinieritas}

Pengujian ini bertujuan untuk menguji apakah model regresi pada penelitian ini menunjukkan adanya korelasi di antara variabel bebas. Untuk mendeteksi ada atau tidaknya multikolinieritas di dalam model regresi dapat digunakan matriks korelasi variabel - variabel bebas. Jika antar variabel bebas memiliki korelasi yang cukup tinggi (umumnya di atas 0,9 ),maka hal ini merupakan indikasi adanya multikolinieritas. Matriks korelasi yang terbentuk dari hasil penglohan SPSS disajikan pada tabel berikut :

Tabel 4.9 


\begin{tabular}{|c|c|c|c|c|}
\hline \multicolumn{5}{|c|}{ Correlations } \\
\hline & & $\mathrm{x} 1$ & $\mathrm{x} 2$ & $\mathrm{y}$ \\
\hline \multirow[t]{3}{*}{$\mathrm{x} 1$} & $\begin{array}{l}\text { Pearson } \\
\text { Correlation }\end{array}$ & 1 & $.584^{* *}$ & $.540^{* *}$ \\
\hline & Sig. (2-tailed) & & .000 & .000 \\
\hline & $\mathrm{N}$ & 48 & 48 & 48 \\
\hline \multirow[t]{3}{*}{$\mathrm{x} 2$} & $\begin{array}{l}\text { Pearson } \\
\text { Correlation }\end{array}$ & & 1 & $.569^{*}$ \\
\hline & Sig. (2-tailed) & .000 & & .000 \\
\hline & $\mathrm{N}$ & 48 & 48 & 48 \\
\hline \multirow[t]{3}{*}{$\mathrm{y}$} & $\begin{array}{l}\text { Pearson } \\
\text { Correlation }\end{array}$ & $.540^{* *}$ & $.569^{* *}$ & \\
\hline & Sig. (2-tailed) & .000 & .000 & \\
\hline & $\mathrm{N}$ & 48 & 48 & 48 \\
\hline
\end{tabular}

**. Correlation is significant at the 0.01 level (2-tailed).

Sumber : Print Out SPSS

Dari tabel di atas dapat diketahui bahwa nilai - nilai tolerance yang diperoleh kurang dari 1 yang diperoleh untuk masing - masing variabel bebas antara 1 sampai 10,sehingga menunjukkan tidak adanya gejala multikolinieritas.

\section{c. Uji Heteroskedastisitas}

Pengujian ini digunakan untuk menguji apakah dalam model regresi terjadi ketidasamaan variance dari residual satu pengamatan ke pengamatan lain.Model yang baik adalah yang homoskedastisitas atau tidak terjadi heteroskedastisitas. Hasil perhitungan korelasi rank spearman SPSS pada penelitian ini adalah sebagai berikut :

\section{Tabel 4.10}

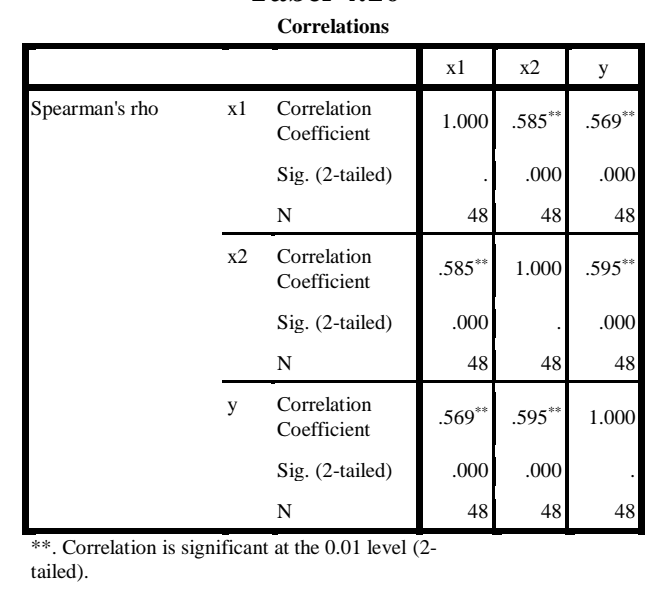

Sumber : Print Out SPSS

Dari hasil perhitungan SPSS yang ditunjukkan pada tabel tersebut,maka diketahui nilai korelasi rank spearman yang diperoleh tidak satupun yang memiliki nilai korelasi yang menunjukkan heteroskedastisitas. Dengan demikian tidak terjadi gejala heteroskedastisitas. Maka model persamaan regresi pada penelitian ini merupakan model persamaan yang homoskedastisitas.

\section{d. Uji Autokorelasi}

Pengujian ini bertujuan menguji apakah dalam sebuah model regresi linier ada korelasi antara kesalahan pengganggu pada periode $t$ dengan kesalahan pada periode t-1 (sebelumnya). Jika terjadi korelasi maka dinamakan ada problem autokorelasi.

Menurut Algifari (1997) Pendeteksian Autokorelasi dapat dilakukan dengan menggunakan metode statistik dari Durbin-Watson (Uji DW) dengan ketentuan sebagai berikut :

1. Nilai DW $<1,10$; ada autokorelasi

2. Nilai DW antara 1,10 s.d. 1,54 ; tanpa kesimpulan

3. Bilai DW antara 1,55 s.d. 2,46 ; tidak ada autokorelalsi

4. Nilai DW antara 2,46 s.d. 2,90 ; tanpa kesimpulan

5. Nilai DW > 2,91; ada autokorelasi

Nilai Durbin-Watson pada olahan SPSS adalah sebagai berikut : 
Persamaan regresi linear berganda mengukur hubungan dari masing - masing variabel bebas terhadap variabel terikatnya. Hal tersebut dapat dilihat dari tabel berikut ini :

Tabel 4.12

Coefficients

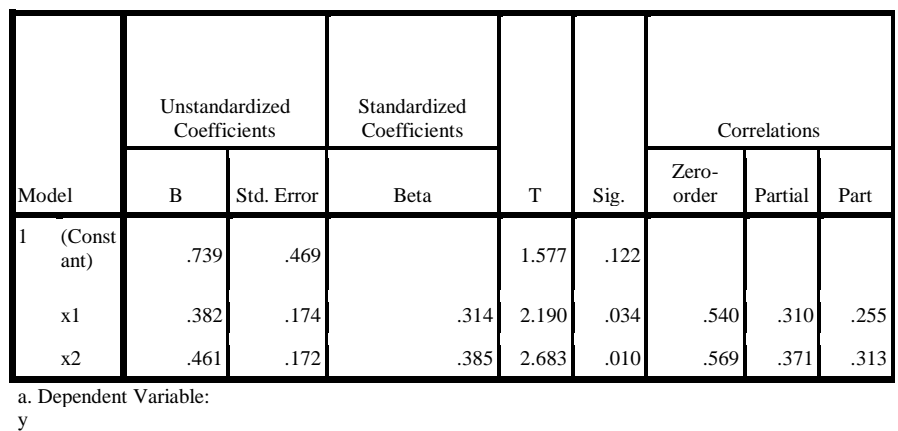

Sumber : Print Out SPSS

Pada hasil pengolahan SPSS yang terdapat dalam lampiran,maka dapat dibuat persamaan regresi linear berganda sebagai berikut :

$\mathrm{Y}=0,739+0,382 \mathrm{X}_{1}+0,461 \mathrm{X}_{2}$

Dari hasil tersebut dapat diartikan :

1. Nilai konstanta adalah 0,739 hal ini menyatakan bahwa tanpa adanya pengaruh variabel bebas $\mathrm{X}_{1}$ (ceramah) dan $\mathrm{X}_{2}$ (pengajaran), maka nilai dari variabel terikat yaitu Y (sikap siswa) adalah sebesar 0,739 .

2. Nilai koefisien regresi dari varibabel bebas $X_{1}$ (ceramah) adalah 0,382 Nilai koefisein tersebut mengandung arti jika nilai variabel bebas $\mathrm{X}_{1}$ ditingkatkan sebesar satu satuan maka akan menyebabkan kenaikan nilai dari variabel terikat yaitu Y (sikap siswa) sebesar 0,382 satuan. Dalam hal ini diasumsikan bahwa nilai dari variabel bebas yang lain adalah konstan atau nol.

3. Nilai koefisien regresi dari varibabel bebas $\mathrm{X}_{2}$ (pengajaran) adalah 0,461. Nilai koefisien tersebut mengandung arti jika nilai variabel bebas $\mathrm{X}_{2}$ ditingkatkan sebesar satu satuan maka akan menyebabkan kenaikan nilai dari variabel terikat yaitu Y (sikap siswa) sebesar 0,461 satuan. Dalam hal ini diasumsikan bahwa nilai dari variabel bebas yang lain adalah konstan atau nol.

\section{Koefisien Korelasi $(\mathbf{R})$ dan Koefisien Determinasi Simultan $\left(\mathbf{R}^{2}\right)$}

Koefisien korelasi mengukur tingkat keeratan hubungan antara variabel bebas dan variabel terikat. Nilai koefisien determinasi simultan yang merupakan hasil pengkuadratan koefisien korelasi menunjukkan prosentase pengaruh variabel bebas simultan terhadap variabel terikat. Dalam penelitian ini variabel bebasnya adalah $\mathrm{X}_{1}$ (ceramah) dan $\mathrm{X}_{2}$ (pengajaran), sedangkan variabel terikatnya adalah sikap siswa.

Nilai koefisein determinasi simultan yang merupakan hasil pengkuadratan koefisien korelasi,menunjukkan prosentase kontribusi variabel bebas yang terdiri dari $\mathrm{X}_{1}$ (ceramah) dan $\mathrm{X}_{2}$ (pengajaran) terhadap variabel terikatnya yaitu sikap siswa.

Dari hasil perhitungan SPSS mengenai koefisien korelasi dan determinasi ditunjukkan oleh tabel di bawah ini.

Tabel 4.13

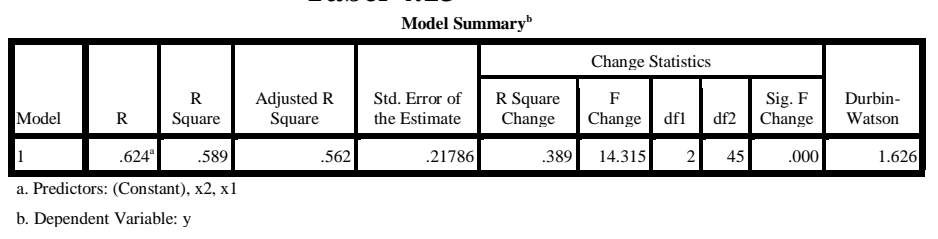

Sumber : Print Out SPSS

Pada tabel tersebut diketahui bahwa nilai koefisien (R) adalah 0,624 atau mendekati 1 Artinya hubungan antara variabel bebas yang meliputi $\mathrm{X}_{1} \mathrm{X}_{1}$ (ceramah) dan $\mathrm{X}_{2}$ (pengajaran) terhadap variabel terikatnya yaitu sikap siswa kuat searah. Artinya jika variabel bebas yang meliputi $\mathrm{X}_{1}$ (ceramah) dan $\mathrm{X}_{2}$ (pengajaran) ditingkatkan, maka variabel terikat yaitu sikap siswa juga akan naik, demikian pula sebaliknya.

Prosentase pengaruh variabel bebas terhadap variabel terikat yang ditunjukkan oleh koefisien determinasi simultan $\left(\mathrm{R}^{2}\right)$ adalah sebesar 0,589 atau 58,9\%. Hal ini berarti bahwa naik turunnya variabel terikat yaitu sikap siswa dipengaruhi oleh variabel bebas yang meliputi $\mathrm{X}_{1}$ (ceramah) dan $\mathrm{X}_{2}$ (pengajaran) sebesar $58,9 \%$ dan sisanya $41,1 \%$ dipengaruhi oleh variabel lain di luar penelitian ini.

\section{Koefisien Korelasi Parsial}

Koefisien korelasi parsial menunjukkan pengaruh mana yang paling dominan dari variabel bebas yaitu $\mathrm{X}_{1}$ (ceramah) dan $\mathrm{X}_{2}$ (pengajaran) terhadap variabel terikat yaitu sikap siswa.

\section{Tabel 4.14}

Coefficients 


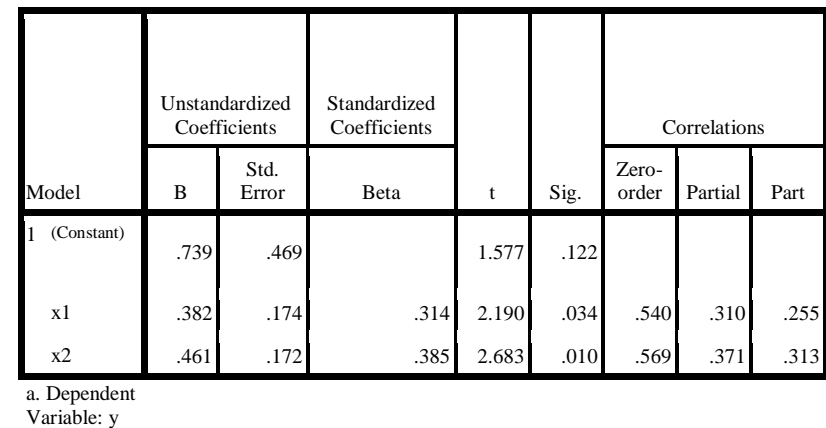

Sumber : Print Out SPSS

Karena $\mathrm{X}_{2}$ (pengajaran) memiliki nilai koefisien korelasi parsial tertinggi yaitu 0,371 dibandingkan dengan variabel $\mathrm{X}_{1}$ (ceramah) sebesar 0,310 maka dapat dikatakan bahwa variabel pengajaran berpengaruh paling dominan terhadap variabel terikat yaitu sikap siswa.

\section{Uji t}

Pada bagian ini hipotesis parsial akan diuji. Pengujian hipotesis parsial ini dapat dilakukan dengan dua cara yaitu dengan membandingkan t-hitung dengan t-tabel (jika thitung > t-tabel maka hipotesis diterima) dan kedua dengan hanya melihat tingkat signifikansinya (sig). Kedua cara ini menghasilkan hasil yang sama. Pada metode pertama, dilakukan dengan cara manual sedangkan dengan cara kedua digunakan hasil print out SPSS. Cara pertama hanya sanggup untuk menguji maksimal pada tingkat $1 \%$ sedangkan cara kedua bisa sampai $0,0000000001 \%$.

Hasilnya dapat dilihat pada tabel berikut ini :

Tabel 4.15

Coefficients

\begin{tabular}{|c|c|c|c|c|c|c|c|c|}
\hline \multirow[b]{2}{*}{ Model } & \multicolumn{2}{|c|}{$\begin{array}{l}\text { Unstandardized } \\
\text { Coefficients }\end{array}$} & \multirow{2}{*}{$\begin{array}{c}\begin{array}{c}\text { Standardized } \\
\text { Coefficients }\end{array} \\
\text { Beta }\end{array}$} & \multirow[b]{2}{*}{ t } & \multirow[b]{2}{*}{ Sig. } & & $\begin{array}{l}\text { dapat d } \\
(0,0 \%) \\
\text { rrelations }\end{array}$ & $\begin{array}{l}\text { lihat pada tingkat signifikan yaitu } 0,000 \\
\text { ang berada di bawah } 5 \% \text {. } \\
\text { Sedangkan untuk menentukan variabel }\end{array}$ \\
\hline & B & Std. Error & & & & $\begin{array}{l}\text { Zero- } \\
\text { order }\end{array}$ & Partimatiabel & terikat adalah dengan melihat nilai \\
\hline 1 (Constant) & .739 & .469 & & 1.577 & .122 & & $\begin{array}{l}\text { koffisie } \\
\text { anflisis }\end{array}$ & $\begin{array}{l}\text { korelasi parsial yang terbesar. Hasil } \\
\text { menghasilkan koefisien korelasi parsial }\end{array}$ \\
\hline $\mathrm{x} 1$ & .382 & 174 & 314 & 2.190 & .034 & .540 & seppertist & abel berikut ini : \\
\hline $\mathrm{x} 2$ & 461 & 172 & .385 & 2.683 & .010 & .569 & \begin{tabular}{l|r|}
.371 & .313 \\
\end{tabular} & \\
\hline
\end{tabular}

a. Dependent Variable: y

\section{Sumber : Print Out SPSS}

Hipotesis parsial yang menyatakan bahwa secara parsial $\mathrm{X}_{1}$ (ceramah) berpengaruh terhadap Y (sikap siswa) TERBUKTI. Hal ini dapat dilihat pada tingkat signifikan $0,034(3,4 \%)$ yang berada di bawah 5\%.
Hipotesis parsial yang menyatakan bahwa secara parsial $\mathrm{X}_{2}$ (pengajaran) berpengaruh terhadap Y (sikap siswa) TERBUKTI. Hal ini dapat dilihat pada tingkat signifikan $0,010(1 \%)$ yang berada di bawah 5\%.

Jadi hipotesis yang menyatakan bahwa secara parsial $\mathrm{X}_{1} \mathrm{X}_{1}$ (ceramah) dan $\mathrm{X}_{2}$ (pengajaran) berpengaruh terhadap sikap siswa, TERBUKTI.

\section{Uji F}

Pada bagian ini hipotesis simultan akan diuji dengan dua cara yaitu dengan membandingkan F-hitung dengan F-tabel (jika Fhitung > F-tabel maka hipotesis diterima) dan kedua hanya dengan melihat tingkat signifikansinya (sig). Kedua cara ini menghasilkan hasil yang sama. Pada metode pertama, dilakukan dengan cara manual sedangkan dengan cara kedua digunakan hasil print out SPSS. Cara pertama hanya sanggup untuk menguji maksimal pada tingkat $1 \%$ sedangkan cara kedua bisa sampai $0,0000000001 \%$. ini :

Hasilnya dapat dilihat pada tabel berikut

Tabel 4.16

ANOVA(b)

\begin{tabular}{|l|r|r|r|r|r|}
\hline Model & Sum of Squares & df & Mean Square & F & Sig. \\
\hline $1 \quad$ Regression & 1.359 & 2 & .679 & 14.315 & $.000^{\mathrm{a}}$ \\
Residual & 2.136 & 45 & .047 & & \\
Total & 3.495 & 47 & & & \\
\hline
\end{tabular}

b. Dependent Variable: $y$

Sumber : Print Out SPSS

Hipotesis yang menyatakan bahwa secara simultan $\mathrm{X}_{1}$ (ceramah) dan $\mathrm{X}_{2}$ (pengajaran) berpengaruh terhadap sikap siswa terbukti. Hal ini dapat d lihat pada tingkat signifikan yaitu 0,000 $(0,0 \%)$ yang berada di bawah 5\% .

Tabel 4.17

Koefisien Korelasi Parsial

\begin{tabular}{|l|c|}
\hline \multicolumn{1}{|c|}{ Variabel } & $\begin{array}{c}\text { Koefisien } \\
\text { Korelasi } \\
\text { Parsial }\end{array}$ \\
\hline Ceramah $\left(\mathrm{X}_{1}\right)$ & 0,310 \\
\hline Pengajaran $\left(\mathrm{X}_{2}\right)$ & 0,371 \\
\hline
\end{tabular}


Sumber : Print Out SPSS.

Hasil analisis menunjukkan bahwa variabel yang dominan berpengaruh terhadap sikap siswa adalah pengajaran $\left(\mathrm{X}_{2}\right)$ karena memiliki koefisien korelasi partial tertinggi yaitu sebesar 0,371 .

\subsection{Pembahasan}

Dari hasil analisis yang telah dilakukan oleh peneliti, di dapatkan hasil pengujian validitas yang menyatakan bahwa alat untuk mengumpulkan data berupa kuesioner yang disusun sudah memenuhi ketentuan valid atau sah. Begitu pula dengan reliabilitas sehingga penelitian dapat dilanjutkan dengan memproses data yang sudah ada.

Prosentase pengaruh variabel bebas terhadap variabel terikat yang ditunjukkan oleh koefisien determinasi simultan $\left(\mathrm{R}^{2}\right)$ adalah sebesar 0,589 atau $58,9 \%$. Hal ini berarti bahwa naik turunnya variabel terikat yaitu sikap siswa dipengaruhi oleh variabel bebas yang meliputi $X_{1}$ (ceramah) dan $\mathrm{X}_{2}$ (pengajaran) sebesar $58,9 \%$ dan sisanya $41,1 \%$ dipengaruhi oleh variabel lain di luar penelitian ini.

Dari uji hipotesis secara parsial ternyata variable bebas baik ceramah maupun pengajaran berpengaruh secara signifikan terhadap peningkatan sikap siswa.

\section{KESIMPULAN DAN SARAN}

\subsection{Kesimpulan}

Dari hasil penelitian yang dilakukan maka diambil kesimpulan sebagai berikut :

1. Variable bebas ceramah dan pengajaran berpengaruh signifikan secara parsial terhadap peningkatan sikap siswa.

2. Variabel bebas yang terdiri dari ceramah dan pengajaran secara bersama - sama berpengaruh signifikan terhadap sikap siswa.

3. Variable bebas pengajaran variable yang paling berpengaruh (dominan) terhadap peningkatan sikap siswa.

\subsection{Saran}

1. Kepada sekolah agar tetap memperhatikan pentingnya variabel - variabel ceramah dan pengajaran karena terbukti mampu mempengaruhi sikap siswa.
2. Meskipun variabel pengajaran mempunyai pengaruh paling dominan dalam peningkatan sikap siswa, manajemen sekolah agar tetap meningkatkan dan memperhatikan variabel - variabel lain yang dapat mempengaruhi sikap siswa.

\section{Daftar pustaka}

Algifari, 1997, "Statistik Induktif Untuk Ekonomi dan Bisnis", Yogyakarta, UUP AMP YKPN

Azwar, S. 2000. Sikap Manusia, Teori dan Pengukuranya. Jogjakarta: Pustaka Pelajar Jogja Offset.

J. Supranto. 1997. "Pengukuran Tingkat kepuasan Pelanggan". Jakarta: Rineka ipta.

Kerlinger, F. N. (1973). Founding Of Behavior Research, Holt. Rinchart and Winston Inc. New York

Singarimbun, Masri dan Sofian Effendi. 1999. Metode Penelitian Survei. Jakarta. PT Pustaka LP3ES

Sugiyono, 2001. Metode Penelitian, Bandung: CV Alfa Beta.

Sugiyono. 2004. Metode Penelitian.Bandung: Alfabeta

Walgito Bimo,1990, Psikologi Sosial, Yogyakarta, Andi 